\title{
Temporal and Spatial Analysis of Flooding and Landslide Disasters in Turkey for Period 1960-2018 ${ }^{[*]}$
}

\author{
Güzide Miray PERİHANOĞLU ${ }^{1 *}$ Himmet KARAMAN ${ }^{2}$ \\ ${ }^{1}$ Van Yüzüncü Yll University, Van Security Vocational School, Emergency and Disaster Management Program, Van, Turkey \\ ${ }^{2}$ Istanbul Technical University, Faculty of Civil Engineering, Department of Geomatics, 34467, Istanbul, Turkey
}

How to cite: Perihanoğlu, G.M. \& Karaman, H. (2020). Temporal and Spatial Analysis of Flooding and Landslide Disasters in Turkey for Period 19602018. J. Anatolian Env. and Anim. Sciences, 5(2), 146-153.

Atıf yapmak için: Perihanoğlu, G.M. \& Karaman, H.. (2020). Türkiye'deki Sel ve Heyelan Afetlerinin 1960-2018 Yılları Arasındaki Zamansal ve Mekansal Analizi. Anadolu Çev. ve Hay. Dergisi, 5(2), 146-153.

: https://orcid.org/0000-0002-2730-590X (iD): https://orcid.org/0000-0003-4923-3561

\begin{abstract}
Turkey, a country affected by natural disasters is natural disasters such as flooding and landslides are seen frequently. Floods and landslides are one of the common natural disasters in Turkey. The use of GIS-based spatial statistical analysis in disaster studies has increased in recent years. From this point, it is essential to examine the spatial distribution of disasters to prevent and mitigate disasters. In this study, flood and landslides disasters that occurred between 1960 and 2018 in Turkey is aimed to determine the spatial analysis using spatial autocorrelation methods. The problem of how these two disaster types distribute is the most pressing thing in disaster risk assessment. Data set was taken from the Disaster Knowledge Base system (TABB) of the Republic Of Turkey Ministry Of Interior Disaster And Emergency Management Presidency. Various indices related to spatial autocorrelation were classified and also they were explained mathematically. Spatial autocorrelation indices such as Moran's I, Getis Ord G, and Geary C were used to determine whether there were clustering in the data set. The rates of flood and landslide in the provinces showing clustering and their distribution are examined and also Flood and landslide distributions in clustered provinces were examined, tested with indices and compared and the results are presented in detail.
\end{abstract}

Keywords: GIS, natural disasters, spatial analysis, spatial autocorrelation, temporal analysis

\section{Türkiye'deki Sel ve Heyelan Afetlerinin 1960-2018 Yılları Arasındaki Zamansal ve Mekansal Analizi}

*Sorumlu yazar:

Güzide Miray PERİHANOĞLU

Van Yüzüncü Yıll Üniversitesi, Van Güvenlik

Meslek Yüksekokulu, Acil Durum ve Afet

Yönetimi Programı, Van, Türkiye

$\triangle$ : gm.perihanoglu@yyu.edu.tr

Cep telefonu : +90 (505) 9378089

Telefon : : +904445065/28307
Öz: Türkiye, doğal afetlerden etkilenen bir ülke olup, sel ve heyelan gibi doğal afetler sık görülmektedir. Sel ve heyelanlar Türkiye'deki yaygın görülen doğal afetlerdendir. Afet çalışmalarında, Coğrafi Bilgi Sistemi(CBS) temelli mekansal istatistik analizinin kullanımı son yıllarda artmıştır. Bu nedenle, afetlerin önlenmesi ve hafifletilmesi için afetlerin mekansal dağılımının incelenmesi önemlidir. Bu çalışmada, Türkiye'de 1960-2018 yılları arasında meydana gelen sel ve heyelan felaketlerinin mekansal otokorelasyon yöntemleri ile mekansal analizi belirlemesi amaçlanmıştır. Afet risk değerlendirmesinde en önemli noktalardan biri bu iki afet türünün nasıl dağılım gösterdiğidir. Çalışmada kullanılan veriler T.C. İçişleri Bakanlığı Afet ve Acil Durum Yönetimi Başkanlığı'nın Türkiye Afet Bilgi Bankası (TABB) sisteminden alınmıştır. Mekansal otokorelasyon ile ilgili çeşitli indeksler sınıflandırılmış olup matematiksel olarak açıklanmıştır. Veri kümesinde kümeleme olup olmadığını belirlemek için Moran I, Getis Ord G ve Geary C gibi mekansal otokorelasyon indisleri kullanılmıştır. Kümelenme gösteren illerde taşkın ve heyelan dağılımları incelenmiş, indisler ile test edilmiş ve karşılaştırılmış olup sonuçlar ayrıntılı bir şekilde sunulmuştur.

Anahtar kelimeler: CBS, doğal afetler, mekansal analiz, mekansal otokorelasyon, zamansal analiz. 


\section{INTRODUCTION}

Disaster is defined as an event that "causing unexpected loss of life and property, injuries and negative environmental consequences, affecting the society economically and socially, cannot be overcome with local resources, need national or international help, often occur due to natural causes, but can also occur due to human causes." According to the center for research on the epidemiology of disasters (CRED) statistics; at least 17\% of all deaths caused by natural disasters in the world occur as a result of landslides. Landslide events and their results are often included in losses caused by the main triggering factor such as earthquake and excessive rainfall. In this respect, their direct effects could not be revealed realistically and they were included in the reports very soon because they were referred to as secondary events (CRED, 2019; Fidan \& Gorum, 2019). Turkey, the majority of the territory is located in Asia, is a country of 780 thousand square kilometers in the bridge position between Europe and Asia. Turkey, because of geological, meteorological and topographical structure is located in a geographical nature often exposed to disasters. Turkey struggles with a variety of disasters such as landslides, floods, earthquakes, rock falls, and avalanches. Disaster types that have the most damaging effects occur in our country as earthquakes, landslides, and floods. Landslides and flooding disasters because of the negative impact it creates in both Turkey and in the nature of the world holds an extremely important place. Landslide incidents are frequently experienced due to wrong land use and geological, climatic, geographic features and are often repeated and turned into disasters (AFAD, 2015; Gokce et al., 2008). It is important to understand the geographical distribution and pattern of natural disasters. Examining the spatial and temporal distributions of landslides offers the opportunity to recognize areas that may be sensitive to landslides in the future. GIS is a very useful technology to show the distribution and pattern of natural disasters. GIS is a powerful tool for the management, analysis, visualization, interpretation and presentation of spatial data (Qiu et al., 2019; Wang et al., 2020). GIS in spatial data analysis provides stronger results when integrated with statistical methods, therefore this integration is demanded in many studies. This study emphasizes the distribution of spatial patterns of natural disasters such as flooding and landslides in Turkey. In the study, for the 1960-2018 period of flooding and landslides in Turkey geographical patterns are analyzed by statistical regions at different levels. According to the Nomenclature of Territorial Units for Statistics (NUTS), Turkey is divided into 12 regions TSI, (2006) (Figure 1).

The data used in the study were obtained from TABB application of the Republic Of Turkey Ministry Of
Interior Disaster And Emergency Management Presidency. These data were used to determine the geographical and temporal distribution of landslides and floods in the country. Mapping and spatial autocorrelation tests were performed using ArcGIS (ESRI) and GeoDa (Spatial Analysis Laboratory, Urbana).

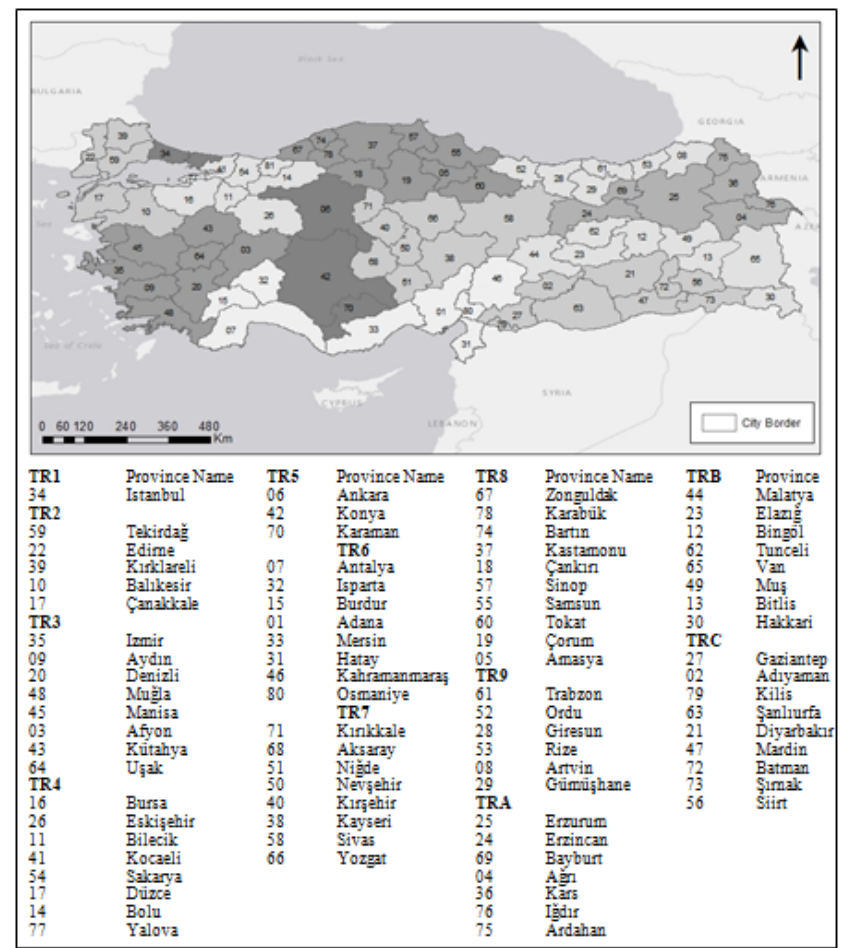

Figure 1. Turkey's statistical regions. The figure was created in ArcGIS using the source of TSI.

\section{MATERIAL AND METHOD}

In this study, data from 81 provincial-level data belonging to landslides and floods that took place in Turkey are used to indicate the spatial distribution. ArcMap software is used to run the analyses and visualize the result maps. The analyses that were run in this study are also described in detail. Classical statistics assume that observations are chosen independently and are spatially independent. Spatial statistics were laid by Tobler. It can be concluded that the correlation in one space is a natural thing occurring between one location and another, and this causing spatial autocorrelation (Hayati et al., 2019; Tobler, 1970). According to Tobler; although everything is related to each other, those in close range tend to be more related than those in long distances. This observation, geographical data analysis, and emphasizes the concept of autocorrelation Salima et al., (2018). Spatial autocorrelation can also be expressed as the process of evaluating the properties of spatial objects as positive or negative depending on the distance. Spatial autocorrelation 
is expressed in three different ways. Positive Autocorrelation is called the clustering of objects close to each other and showing similar properties. Negative Autocorrelation is defined as the objects being close to each other but not showing similar characteristics. And finally, zero autocorrelation means that there is a random pattern and attributes are independent of location (Goodchild, 1986; Griffith, 1992). Spatial autocorrelation indices such as Moran's I, Geary C and Gets G are frequently used in the literature. The first step in spatial autocorrelation analysis is to create spatial weights. The distance of objects is entered as a weight to define spatial relationships; here autocorrelation of neighboring objects is more important than autocorrelation of distant objects (Anselin, 2003; Redecker et al., 2020).

Spatial Weight Matrix: An important aspect of defining spatial autocorrelation is the determination of "neighborhoods" of the data set in a particular area. The neighborhood structure of a dataset is optimally formulated in the form of a spatial weight matrix W. The spatial weight matrix $n x n$ is a positive matrix also it expresses the existence of a neighboring relationship as a binary relationship Fischer and Wang, (2011). Spatial Weight Matrix (SWM), spatial between observations it is a clear expression of addiction. In other words, spatial values exist between values in a dataset. It provides a numerical expression of relationships and can be determined in many ways. The weight matrix can be calculated based on the polygonal border (shape) contiguity or distance between points. It takes 1 if the zone boundaries are shared and 0 if not shared in the contiguity based weight matrix. It means that symmetric matrix (Anselin, 2002; Seya, 2020; Zeng, 2019). The most used SWMs in the literature are known as rook's case, queen's case, nearest neighbor, reverse distance, fixed distance. In the rook based contiguity relationship, only the edge neighborhoods are taken into account in four directions adjacent to each cell while in the queen-based relationship, neighbors in all directions are taken into account. Moreover, in Bishops contiguity relationship only is taken into account the diagonals of the location Mathur, (2015). First-order rook contiguity SWM was created in the study because first-order rook contiguity SWM describes with neighbors observations that share common boundaries.

Moran's I, Geary C and Gets Ord G Indices: The Moran's index was developed by Patrick A Alfred Pierce Moran in 1950 as a statistical tool to calculate spatial autocorrelation Moran, (1950). Moran's I and Geary c indices have statistic local versions that are used to define similar values. In literature, Moran's I index is one of the most widely used indices to show spatiality. Moran's I is an indicator for both measuring spatial autocorrelation and distinguishing the spatial clusters and outliers. In order to calculate the Moran's I, it first calculates mean value then both the values of neighboring features and target feature compare with the mean value. Moran's I can be defined as equation 1:

$$
I=\frac{N \sum_{i} \sum_{j} w_{i j}\left(x_{i}-\bar{x}\right)\left(x_{j}-\bar{x}\right)}{\left(\sum_{i}^{n} \sum_{j}^{n} w_{i j} \sum_{i}\left(x_{i}-\bar{x}\right)^{2}\right.}
$$

Here, the number of spatial units is denoted by $\mathrm{N}$. Wij represents the spatially weighted matrix, while $\mathrm{Xi}$ and $\mathrm{Xj}$ represent the value of the variables (Pujianto et al., 2020; Sung et al., 2020). The calculated I value takes a value between $[-1,1]$. It means that, a positive autocorrelation when the value converges to 1 , a negative autocorrelation when converging towards -1 . If I value is equal to zero, it means that there is no spatial autocorrelation. Positive spatial autocorrelation in the dataset means that similar values tend to be spatially clustered, but in negative spatial autocorrelation it means that higher values tend to accumulate near the low values; this means that similar values are not clustered in space (Aksha et al., 2018; Mitchel, 2005).

Although the calculation of Geary C and Moran's I indices are similar, their interpretation is different. C value calculated in Geary $\mathrm{C}$ index gets value in the range from 0 to 2 . Typically it can be interpreted as positive spatial autocorrelation if the $\mathrm{C}$ value takes values less than 1 (that is, between 0 and 1), and negative spatial autocorrelation if it indicates values greater than 1 (that is between 1 and 2) (Geary, 1954; Wu \& Kemp, 2019). Formally Geary c index is defined as Eq. (2):

$$
C=\frac{N \sum_{i} \sum_{j} w_{i j}\left(x_{i}-x_{j}\right)^{2}}{2\left(\sum_{i} \sum_{j} w_{i j}\right) \sum_{i}\left(x_{i}-\bar{x}\right)^{2}}
$$

While Moran's I compare the neighboring values with the mean value, Geary $\mathrm{C}$ index compares the two neighboring values directly to each other Anselin, (2019). $\mathrm{Gi}$ index calculates the using the distance-based neighborhood or adjacent features. To calculate Gi index (equation 3), once the value of each neighbor is multiplied by the weight of the target neighboring pair and the results are collected, the founded value is divided by the sum of the values of all features in the study area (Getis et al., 1992 ; Levine, 2013). Getis ord G index mathematical is defined as follows.

$$
G_{i}(d)=\frac{\sum_{j} w_{i j}(d) x_{j}}{\sum_{j} x_{j}}
$$

While the attribute values are multiplied by 1 neighbors feature, the others are multiplied by 0 . Therefore only the values of the neighbors are included. If the calculated $G$ value is larger from the expected value, it 
indicates that the high values are clustered together, which indicates the hot spots. In contrast, if the value of $G$ is less than the expected value, the low values are clustered together, which indicates cold spots (Mitchel, 2005; Ren et al., 2020).

The geostatistics program GeoDa used in the study is a free and open-source software tool which is an introduction to spatial data analysis. It is designed to provide new insights from data analysis by exploring and modeling spatial patterns. GeoDa was developed by Dr. Luc Anselin and his team. The program provides a userfriendly and graphical interface for the implementation of spatial data analysis (ESDA) methods such as spatial autocorrelation statistics for aggregate data and basic spatial regression analysis for point and polygon data GeoDa, (2003). ArcGIS is software produced by ESRI and helps to solve all GIS related problems. ArcGIS provides a scalable framework for implementing GIS for a single user or many users on desktops, in servers, over the webs, and in the field.

\section{RESULTS AND DISCUSSION}

According to TABB data, all provinces except Nevsehir have experienced a flood incident. The total number of floods recorded is 776. Flooding disaster occurred the most frequently in Istanbul (52), Erzurum (49), Gümüşhane (39), Ankara (29) (Figure 2).

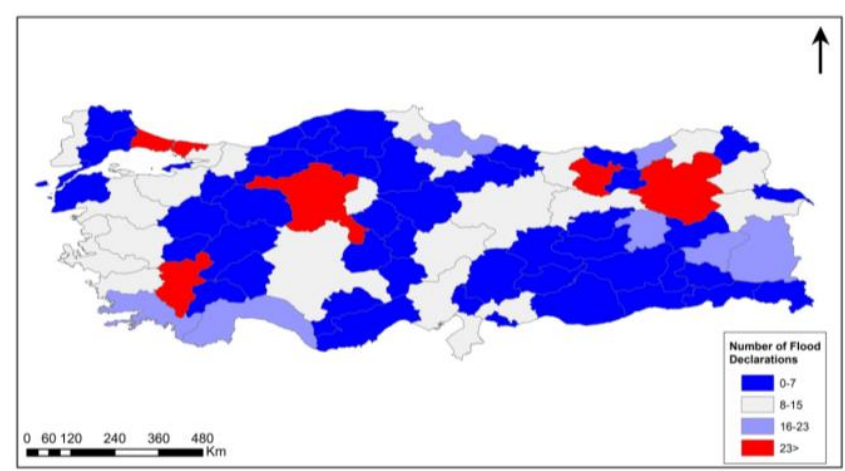

Figure 2. The Number of flood declarations in Turkey. According the TABB data, the map shows the number of times floods were declared in Turkey.

In the assessment made for landslide disaster, it is seen that all provinces are affected to a specific extent by a landslide. When provinces are examined one by one according to the number of landslide incidents; the most common landslide events are observed in Artvin (76), Trabzon (73), Rize (68), Giresun (61) and Erzurum (60)(Figure 3).

Firstly, Moran's I value was tested by using the spatial weight matrix formed according to neighborhood relationships in order to examine the spatial autocorrelation of landslide and flood data. The Moran scatter plot is a useful tool that can visually describe the relationship between observations and their neighbors. A Moran scatter plot is a plot that is variable of interest on the $\mathrm{x}$-axis and the spatial lag on the $\mathrm{y}$-axis. Figures 4 and 5 show the relationship between the landslide and flood numbers (X-axis) and the mean values of the neighboring landslide and flood number (Y-axis) whose weight is calculated using first-order rook contiguity spatial weight matrix.

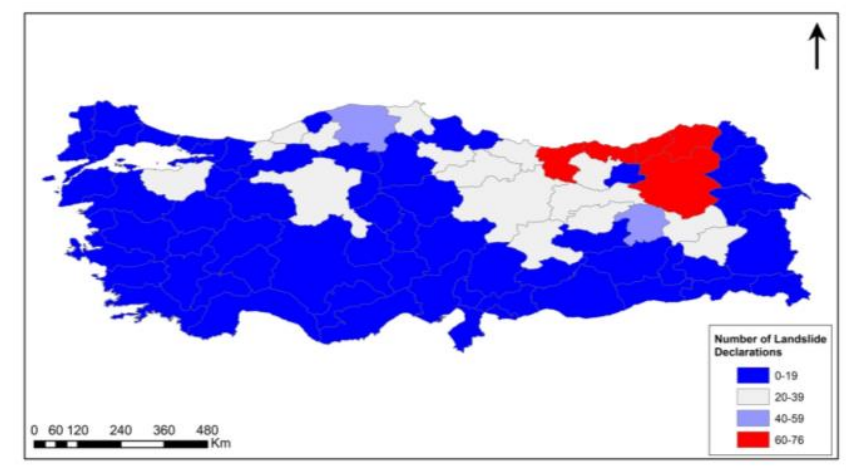

Figure 3. The Number of landslide declarations in Turkey. According the TABB data, The map shows the number of times landslides were declared in Turkey.

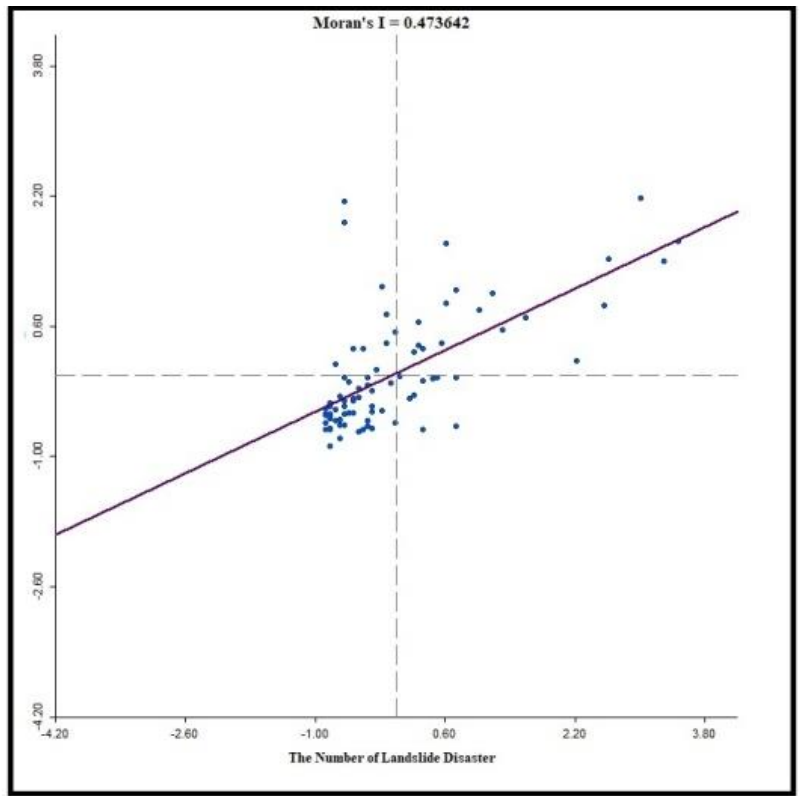

Figure 4. Moran scatter plot of the number of landslide disasters of provinces in Turkey.

In the Moran scatter plot, there are four quarters express the type of spatial relationship between observations and their neighbors. This scatter plot shows the value of the original variable (the number of landslide disaster) on the horizontal axis and the spatial lag of the variable (average the number of landslide disaster neighbors) on the vertical axis.

The four quarters on the graph are expressed as high-high (top right), low-low (bottom left), high-low (bottom right) and low-high (top left). While high-high 
(upper right) and low-low (lower left) indicate positive spatial autocorrelation, low-high (upper left) indicate negative spatial autocorrelation. The upper-right quarter of the graph corresponds to the areas where the provinces with the highest landslide numbers are surrounded by the provinces with the highest landslide numbers. The leftlower quarter indicates that the provinces with low landslides again surrounded by the provinces with low landslides (low-low).

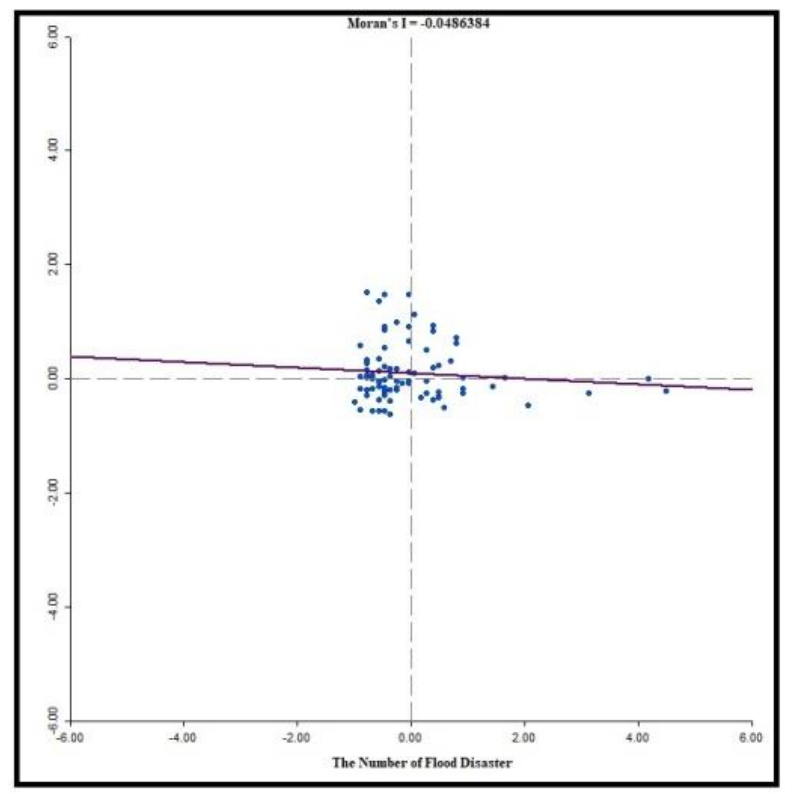

Figure 5. Moran scatter plot of the number of the flood disaster of provinces in Turkey.

In our study, the slope of the regression line in the Moran scatter plot for landslides is 0.473642 while the slope of the regression line in the Moran scatter plot for the flood is -0.0486384 . In this case, the landslide distribution in Turkey implies that there is positive spatial autocorrelation. In the flood distribution in Turkey is seen as negative autocorrelation. Therefore, dispersed values are observed.

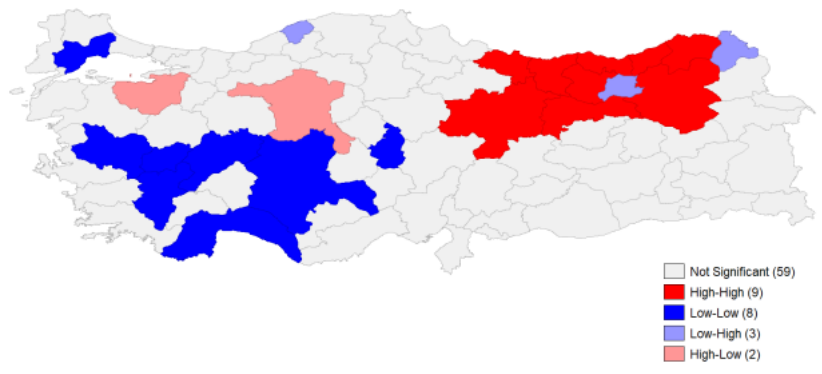

Figure 6. Spatial distribution of the number of landslides according to Moran's I index.

The landslide map obtained by Moran's I method is shown in Figure 6. The high-high and low-low locations is that mean spatial clusters, although the high-low and low-high locations are typically referred to as spatial outliers. Accordingly, landslide settlements in Turkey, particularly are concentrated in the east and northeast of the Black Sea region of Anatolia. On the other hand, it is observed that landslide disasters constitute a significant spatial class in low-low classification too (Table 1). The regions that indicate low-low locations are the Aegean, Western Anatolia, Central Anatolia, and the Mediterranean. In our study, it is understood that there is no clustering since the Moran's value calculated for flood disaster is below zero. In other words, it appears to be a dispersed pattern. It is shown in figure 7.

Table 1. According to Moran's I analysis, the distribution of landslide events according to settlement units.

\begin{tabular}{lll}
\hline Class & Statistical Region & Province \\
\hline \multirow{2}{*}{ High-High } & TR9 & Giresun,Rize,Ordu,Artvin,Trabzon,Gümüşhane \\
& TRA & Erzurum,Erzincan \\
& TR3 & Denizli,Manisa, Uşak,Afyon \\
& TR2 & Tekirdağ \\
Low-Low & TR6 & Antalya \\
& TR7 & Nevşehir \\
& TR5 & Konya \\
\hline
\end{tabular}

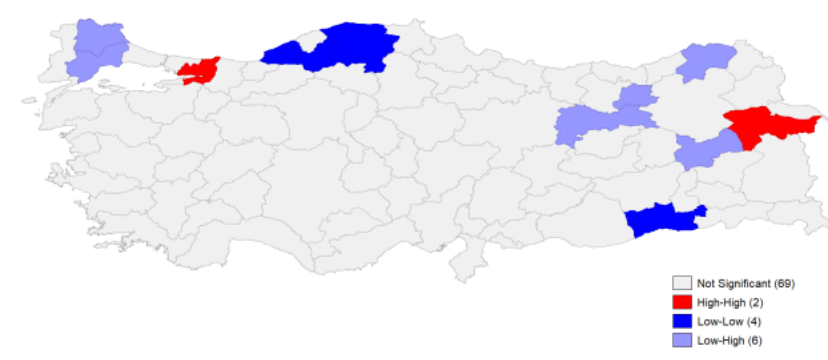

Figure 7. Spatial distribution of the number of flood disaster according to Moran's I index.

Another spatial autocorrelation index used in this study is Geary C. Positive spatial autocorrelation in Geary $\mathrm{C}$ method is defined as small differences imply similarity. This association can identify as high-high or low-low. For negative spatial autocorrelation in Geary $\mathrm{C}$ implies large values imply dissimilarity.

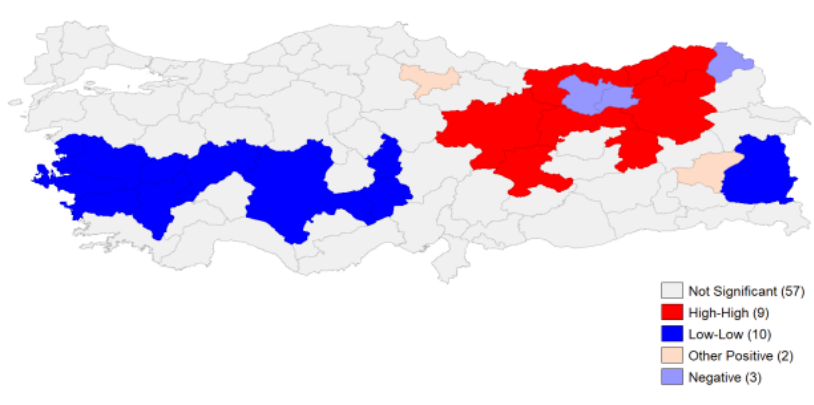

Figure 8. Spatial distribution of the number of landslides according to Geary $\mathrm{C}$ index.

As shown in Figure 8, there are 9 such high-high locations and 8 low-low locations. There are 2 locations with positive spatial autocorrelation classified as other 
positive in this case. There are three observations with negative spatial autocorrelation. Three locations are shown dispersed. According to the Geary c index, the settlements where the number of landslides is high, are concentrated in the Black Sea region (Artvin, Rize, Trabzon, Giresun), North-eastern Anatolia region (Erzurum, Erzincan), Middle East Anatolia (Bingöl, Malatya). It is observed that the provinces showing low-low relationship where the number of landslides is low, constitute a spatial class in the Aegean region (Afyon, Denizli, Manisa, Aydin), Mediterranean region (Adana), Central Anatolia region (Niğde, Nevşehir) and Western Anatolia region (Konya). On the other hand, as shown in Figure 9, no significant spatial distribution was observed for floods.

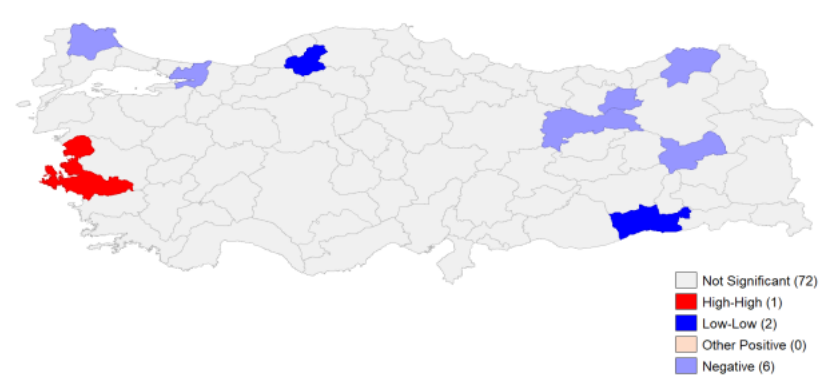

Figure 9. Spatial distribution of the number of floods according to Geary $\mathrm{C}$ index.

Getis and Ord suggested third indices for local spatial autocorrelation. The Get-Ord G index is interpreted as high-high clustering or hot spots if the $G$ value is larger than the expected value and it is interpreted as low-low clustering or cold spots if the $G$ value is smaller than the expected value. While Local Moran and Local Geary statistics consider the spatial outliers, the Getis-Ord G does not take into account spatial outliers.

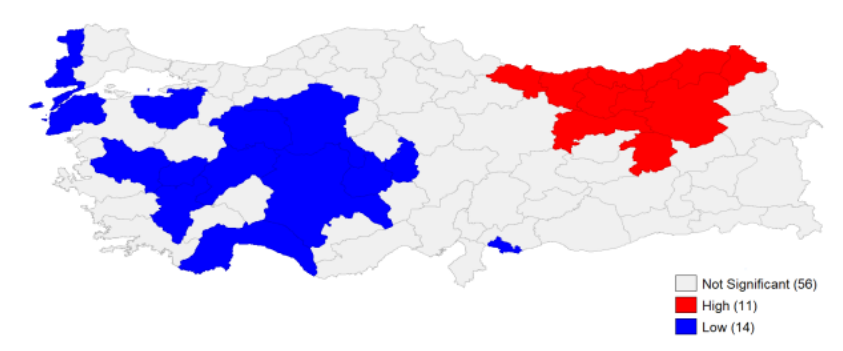

Figure 10. Spatial distribution of the number of landslides according to Getis Ord G index.

The corresponding cluster map, illustrated in Figure 10, shows 11 high-high cluster cores or hot spots (in red on the map), and 14 low-low cluster cores or cold spots (in blue on the map). For landslide data, it was observed that the locations determined for Local Moran were the same.

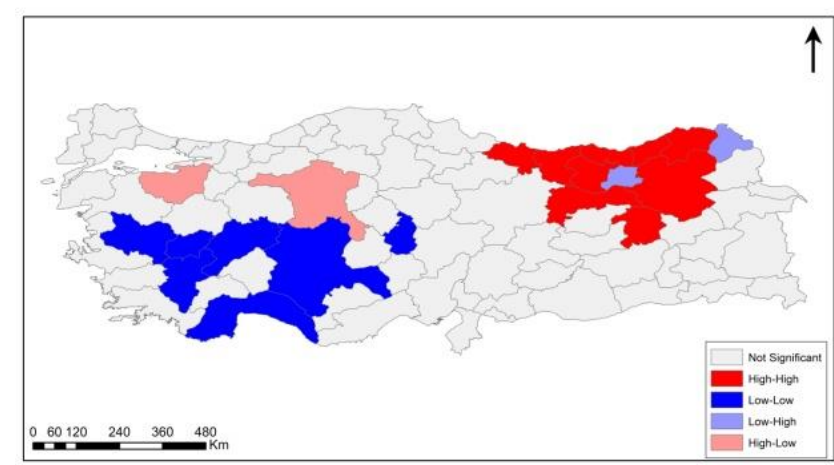

Figure 11. Spatial distribution of the number of landslides according to ArcGIS.

ArcGIS is a full-fledged GIS application with editing, mapping, data analysis and database management features. While the GeoDa program has the advantage of being free software for spatial data analysis that focuses on time series and spatial clustering, there are also cartographically insufficient aspects (Figure 11).

\section{CONCLUSION}

Spatial autocorrelation can be a useful tool to examine how spatial patterns change over time. This study has tried to investigate and reveal spatial patterns of landslides and floods in Turkey. In this respect, the spatial distribution of landslides and flood disasters were examined using spatial autocorrelation techniques. Moran's I value was calculated for both landslide and flood disaster and relationship types were shown with Moran scatter diagram. Local spatial relations were investigated by local analysis.

As a result, the Eastern Black Sea region and North-East Anatolia around the cities of Erzurum and Erzincan was emerged as the mostly landslide occurred settlements with the clusters of three applied indices. It helps the decision makers to direct the strategic efforts to reduce landslide damages or their risks and concentrate the efforts on these regions. According to TABB data TABB, (2019) flood incidents have occurred in all provinces of the study region Turkey within the studied time period. Clustering was not observed when these indexes were applied due to the dispersed data of the provinces. That's why, different spatial indices which do not focus on the location but the distribution of the events with respect to reasons of the incidents could be helpful for the dispersed data for the future studies. An example for flood another incidence like meteorological events may also be added with the topography and the most prone areas for flood can be identified with the TABB (2019) data. Presenting the distribution of disasters with spatial autocorrelation methods will give a different dimension to the studies. And 
using the real world data like in TABB will help to estimate the upcoming disasters in the future.

\section{ACKNOWLEDGEMENTS}

The authors are thankful to Turkey Disaster Knowledge Base (TABB) which is being carried out by the Ministry of Interior of Disaster and Emergency Management Presidency of Turkey.

\section{REFERENCES}

AFAD. (2015). Preparation of integrated hazard maps landslide-rock fall basic guide. Ministry of Interior Disaster and Emergency Management Presidency, Ankara, Turkey,152p.

Aksha, S.K., Juran, L. \& Resler, L.M. (2018). Spatial and temporal analysis of natural hazard mortality in Nepal. Environmental Hazards, 17(2), 163179. DOI: $10.1080 / 17477891.2017 .1398630$

Anselin, L. (2002). Under the hood issues in the specification and interpretation of spatial regression models. Agricultural Economics, 27(3), 247-267. DOI: 10.1111/j.15740862.2002.tb00120.x

Anselin, L. (2003). Spatial externalities, spatial multipliers, and spatial econometrics. International Regional Science Review, 26(2), 153-166. DOI: 10.1177/0160017602250972

Anselin, L. (2019). A local indicator of multivariate spatial association: Extending Geary's c. Geographical Analysis $\quad \mathbf{5 1}(2), \quad$ 133-150. DOI: 10.1111/gean.12164

CRED. (2019). Natural disaster in 2018. Centre for Research on the Epidemiology of Disasters (CRED), Brussels, Belgium, 8p.

Fidan, S. \& Gorum, T. (2019). Spatial and temporal distribution of fatal landslides in Turkey from 1929 to 2018. 1st Istanbul International Geography Congress, 20-22 June 2019, Istanbul, Turkey,1109-1110.

Fischer, M. \& Wang, J. (2011). Spatial data analysis models, methods and techniques. Springer Briefs in Regional Science, 82p.

Geary, R.C. (1954). The contiguity ratio and statistical mapping. The Incorporated Statistician 5(3), 115145.

GeoDa. (2003). GeoDa user's guide, Spatial Analysis Laboratory Department of Agricultural and Consumer Economics University of Illinois, Urbana.
Getis, A. \& Ord, J.K. (1992). The analysis of spatial association by use of distance statistics. Geographical Analysis 24(3), 189-206.

Gokce, O., Ozden, Ş. \& Demir, A. (2008). Spatial and statistical distribution of disasters in Turkey, Republic of Turkey Ministry of Public Works and Settlement General Directorate of Disaster Affairs and Disaster Damage Assessment Studies Department, Ankara, Turkey, 127p.

Goodchild, M. (1986). Spatial autocorrelation. GeoBooks, Norwich, UK, 57p.

Griffith, D.A. (1992). What is spatial autocorrelation? Reflections on the past 25 years of spatial statistics. L'Espace Ge'ographique 21, 265-80.

Hayati, M., Purnamasari, I. \& Wahyuningsih, S. (2019). Analysis of spatial autocorrelation of diarrhea events in East Kalimantan in 2015-2017 using a local indicator of spatial autocorrelation. Journal of Physics: Conference Series, 1277 (2019). DOI: 10.1088/1742-6596/1277/1/012045

Levine, N. (2013). CrimeStat IV: Spatial Autocorrelation Statistics, In: Levine, N. (Ed), A Spatial Statistics Program for the Analysis of Crime Incident Locations (version 4.0), Ned Levine \& Associates, Houston, TX, and the National Institute of Justice, Washington, DC.

Mathur, M. (2015). Spatial autocorrelation analysis in plant population: An overview. Journal of Applied and Natural Science 7 (1), 501 - 513. DOI: 10.31018/jans.v7i1.639

Mitchel, A. (2005). The ESRI guide to GIS analysis, Volume 2: Spatial measurements and statistics. 1st ed., ESRI, California, USA, 252p.

Moran, P.A.P. (1950). Notes on continuous stochastic phenomena. Biometrika, 37, 17-23.

Pujianto, M., Raharjo, M., \& Nurjazuli, N. (2020). Spatial pattern analysis on Dengue Hemorrhagic Fever (DHF) disease in Tanjung Emas port area using Moran index. International Journal of English Literature and Social Sciences (IJELS), 5(2). DOI: 10.22161/ijels.52.11

Qiu, H., Cui, Y., Hu, S., Yang, D., Pei, Y., \& Yang, W. (2019). Temporal and spatial distributions of landslides in the Qinba Mountains, Shaanxi Province, China. Geomatics, Natural Hazards and Risk, 10(1), 599-621. DOI: 10.1080/19475705.2018.1536080

Redecker, A., Burian, J., Moos, N., \& Macků, K. (2020). Spatial Analysis in Geomatics. In: Paszto,V., Jürgens, C., Tominc, P. \& Burian, J. (Ed), Spationomy 65-92p, Springer, Cham, Switzerland. 
Ren, H., Shang, Y. \& Zhang, S. (2020). Measuring the spatiotemporal variations of vegetation net primary productivity in Inner Mongolia using spatial autocorrelation. Ecological Indicators, 112, 106-108. DOI: 10.1016/j.ecolind.2020.106108

Salima, B. \& Bellefon, M.P. (2018). Spatial autocorrelation indices. In: Loonis, V. \& Bellefon, M. P. (Ed), Handbook of spatial analysis, 1st ed., 52-68p, Insee, Eurostat, Montrouge, France.

Seya, H. (2020). Global and local indicators of spatial associations. In: Yamagata, Y. \& Seya, H. (Ed), Spatial Analysis Using Big Data, 33-56p, Elsevier.

Sung, C. H. \& Liaw, S.C. (2020). A GIS-based approach for assessing social vulnerability to flood and debris flow hazards. International Journal of Disaster Risk Reduction, 46. DOI: 10.1016/j.ijdrr.2020.101531

TABB. (2019). Turkey disaster knowledge base (analysis and document module), The Ministry of Interior of Disaster and Emergency Management Presidency of Turkey (AFAD).

Tobler, W.R. (1970). A computer movie simulating urban growth in the Detroit region. Economic Geography, 46, 234-240.

TSI. (2006). The data: coverage, periodicity and timeliness. Turkish Statistical Institute, Turkey, $8 \mathrm{p}$.

Wang, Q., Zhang, Q.P., Liu, Y.Y., Tong, L.J., Zhang, Y.Z., Li, X.Y. \& Li, J.I. (2020). Characterizing the spatial distribution of typical natural disaster vulnerability in China from 2010 to 2017. Natural Hazards, 100(1), 3-15. DOI: 10.1007/s11069019-03656-7

Wu, A.M. \& Kemp, K.K. (2019). Global measures of spatial association. In: Wilson, J.P. (Ed), The geographic information science \& technology body of knowledge, 1st ed., UCGIS, New York, USA. DOI: $10.22224 /$ gistbok/2019.1.12

Zeng, C. (2019). Spatial spillover effect on land conveyance fee-A multi-scheme investigation in Wuhan agglomeration. Land Use Policy, 89, 104196. DOI: 10.1016/j.landusepol.2019.104196 